\title{
Chronic diarrhea due to glucoamylase deficiency
}

INSERM

\section{Source}

INSERM. (1999). Orphanet: an online rare disease and orphan drug data base. Chronic diarrhea due to glucoamylase deficiency. ORPHA:103907

This syndrome is characterised by chronic diarrhoea in infancy or childhood in association with intestinal glucoamylase deficiency. 